\begin{tabular}{ll}
\hline 論 \\
\hline
\end{tabular}

\title{
下咽頭癌治療の変遷と展望
}

\author{
田中 信 三

\section{Change and its Significance in the Treatment of Hypopharyngeal Carcinoma}

\author{
Shinzo Tanaka \\ (Kyoto University)
}

\begin{abstract}
Change and its significance in the treatment of the hypopharyngeal carcinoma (HPC) are discussed, chiefly based on the author's experiences. In the nineteen-seventies and eighties, the prognosis of HPC was poor, and the 5 -year over-all survival was only $24 \%$ in 173 patients. Locoregional recurrence was the most serious problem. To improve locoregional control, we introduced extended surgery with reconstruction using a free jejunal graft, in which a safety margin of $3 \mathrm{~cm}$ or more was secured at the primary site while bilateral retropharyngeal and paratracheal dissections were added to bilateral radical neck dissections. This treatment achieved a disease-specific 3 -year survival of $64 \%$ for patients with advanced (stage III, IV) HPC, which was significantly better than that of patients treated by previous methods. Furthermore, postoperative radiotherapy was introduced for advanced HPC treatment, in which a $50 \mathrm{~Gy}$ dose was basically used to irradiate the bilateral neck and a $10 \mathrm{~Gy}$ dose was locally added when a retropharyngeal lymphnode metastasis was histopathologically identified or the number of lymphnode metastasis was three or more. In the recent five years, the disease-specific 3-year survival reached $81 \%$ in 39 advanced HPC patients. During this period, we endeavored to conserve in laryngeal functions for patients with early (stage I, II) HPC by performing a radiotherapy or partial pharyngectomy. In 14 early HPC patients, there was no recurrence and the larynx was well conserved in eleven. We also developed a new method of reconstruction after partial laryngopharyngectomy, in which aspiration was well prevented by reconsfructing the supraglottis and hypopharynx using hyoid bone attached to sternohyoid muscle and free forearm flap. Progress in surgical reconstruction techniques and radiotherapy changed the treatment of HPC, providing a better prognosis for advanced HPC patients and a better life quality for early HPC patients.
\end{abstract}

Key words : hypopharyngeal carcinoma, extended surgery, free jejunal graft, radiotherapy, partial laryngopharyngectomy

はじめに

下咽頭癌は耳鼻咽喉科・頭頸部外科領域では最も予後 の悪い腫瘍の一つといわれてきた．筆者が医師になりた ての頃（1980 年頃）には, 下咽頭癌の患者が入院してく ると，どのように治すのかを検討する前に，どのような
最期を迎えるのがふさわしいかを考えてしまうことが多 かった。 当時は, 指導医も含めて, 下咽頭癌は治らない ものであるという考え方が支配的であり，再発率の高い 手術や副作用の強い高線量放射線照射を行らよりは何も しないほうがましなのではないかと思うことが多かっ 
た.このような考え方は今でもない訳ではない。しかし ながら，当時から今日まで，再建方法や術後管理を含め た手術治療は明らかに進歩しており, 放射線治療や抗癌 剤治療もかなり精錬されてきた。こうした技術的進歩は， 当然,下咽頭癌の治療にも積極的に取り入られてきたが, 果たして下咽頭癌の患者にその恩恵があったのであろう か? この問いに答えるのは，実は，大変難しい，なぜな らば，下咽頭癌の患者はもともと多くない上に，施設に よって治療方針も治療技術も大きく異なる，その結果， 施設間の成績は大きくばらつき，多施設で集計した多数 例のデータは統計学的に意味の少ないものになってい る、筆者は，幸い，これまで頭頸部癌を比較的多く扱う 施設で下咽頭癌の治療方針を決め，実際に治療する仕事 を行ってきた．そこで，本稿では，筆者が扱ってきた症 例を中心にして，下咽頭癌の治療方法と治療成績を経時 的に分析し，下咽頭癌治療の変遷とその意義を検証する. また，下咽頭治療の現状をふまえて今後の課題を展望す る.

下咽頭癌の治療成績は本当に悪かった

昔の下咽頭癌の治療成績はどのぐらい悪かったのか? 筆者は久留米大学病院で 1970 年代から 80 年代までの 20
年間にわたる下咽頭癌患者の治療経過を調べる機会を得 $た^{11}$. 当時から久留米大学は頭頸部癌の治療において中 核的施設であり多地域から多くの患者が集まっていた が，下咽頭癌は 20 年間で 173 例という数であった。 173 例のうち，治癒を目的にした手術を行いえたもの（根治 手術例）は 138 例，手術不能や手術拒否などで姑息的に 治療したもの（非根治手術例）は 35 例であり, 図 1 のよ うに, 全体の 5 年生存率は $24 \%$, 根治手術例でも $29 \%$ と かなり悪い成績であった。根治手術例に限れば他病死を 打ち切り例にした疾患特異的生存率は統計上で $41 \%$ で あったが，生存者のあまりの少なさに暗澹たる思いをし たものである。

なぜこれほど下咽頭癌の成績が悪かったのか? 最も はっきりしているのは局所制御が悪かったことである. 表 1 に示すように, 死亡例の $37 \%$ が局所の再発か頸部り ンパ節再発で死亡したが，これらの多くに咽喉頭全摘や 根治的頸部郭清が施行されていたことを考慮すると，下 咽頭癌はそもそもが局所制御の難しい癌であることがわ かる．また，死亡例のなかには手術死や合併症死む散見 され，手術法や術後管理の問題もあったと思われる，そ の他, 肺転移などの遠隔転移が少なくない，食道癌など の重複癌が合併しやすい，進行癌で発見されることが多

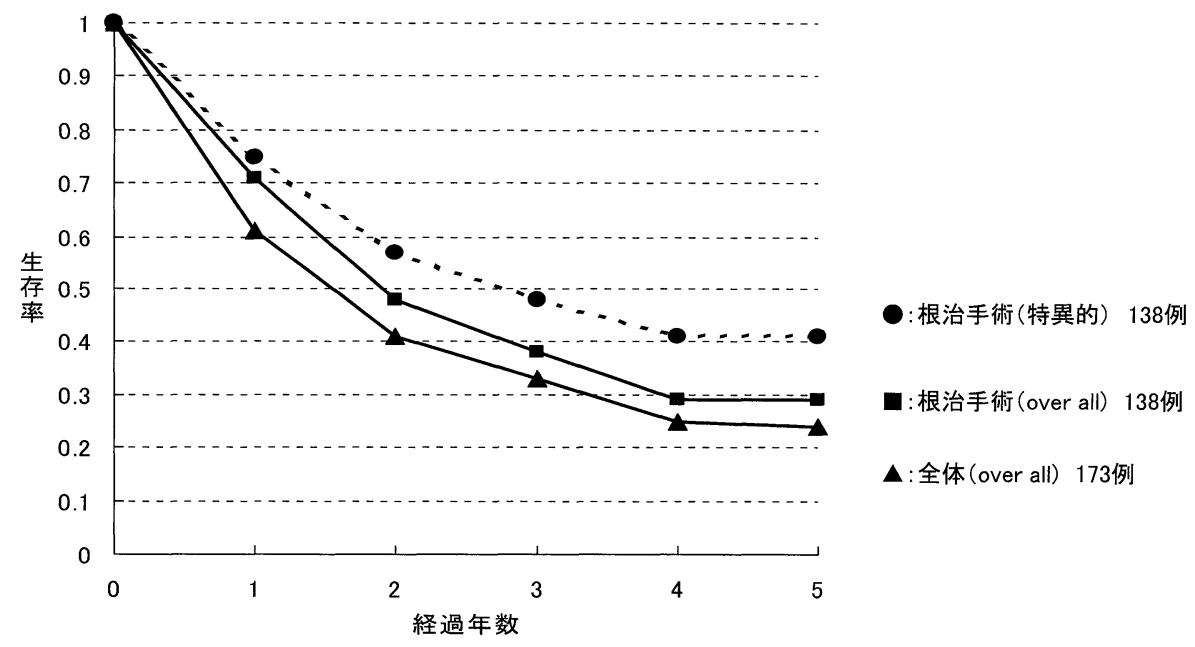

図 $11971 \sim 90$ 年, 久留米大学における下咽頭癌症例の生存率

表 $11971 \sim 90$ 年，久留米大学における下咽頭癌症例の死因

\begin{tabular}{c|ccccc|c|c}
\hline \hline 死因 & 原発巣 & 頸部リンパ節 & 遠隔転移 & 手術 & 合併症 & 他病死 & 計 \\
\hline 例数 & 15 & 19 & 20 & 5 & 8 & 24 & 91
\end{tabular}


い，なども無視できない要因であった。

当時の久留米大学では頭頸部癌のそれぞれに対して種 類を問わず $50 \%$ 以上の治癒を目指していた. その意味で は下咽頭癌は最重点疾患の一つであり, 生存率を上げる ための試みが積極的に行われた。

\section{遊離空腸の利用で広範切除が可能になった}

下咽頭癌の局所制御を向上させるためには, 原発巣を より広範囲に切除し頸部リンパ節をより広範囲に郭清す ることが一つの有力な手段をして期待できる。しかしな がら, 1980 年代に頻用されていた局所皮弁や有茎皮弁に よる再建では部分壊死や瘻孔を生じることが多く, 術後 の重篤な合併症を防ぐために切除範囲や郭清範囲はおの ずと限られたものになっていた，広範切除には血行のよ い大きな組織で再建する必要がある，遊離空腸による下 咽頭・頸部食道の再建は, まさに, 広範切除のために導 入したものであり, 筆者は 1989 年以降, 咽喉頭全摘の再 建にほとんど全例で用いてきた2).

遊離空腸の再建は形成外科と消化器外科とのチーム医 療で始めたが, 当初は, 移植空腸の壊死や瘻孔, 術後の 嚥下障害などさまざまなトラブルがあった ${ }^{3 / 4)}$.しかしな がら, 微小血管吻合の技術の進歩に伴い空腸壊死はほと んど生じなくなり瘦孔もめったに起こらなくなってい る. また，なるべく短い空腸を端々吻合することで燕下 障害も減少している5 . 今や, 遊離空腸による再建は, 咽 喉頭全摘における第 1 選択枝といっても過言ではない.
遊離空腸移植を併用した広範切除で治療成績は上がっ たのか? 久留米大学の症例で空腸再建群とそれ以前の再 建群で生存率を比較したところ, 図 2 に示すように， 3 年生存率が空腸再建群では $64 \%$, それ以前の再建群では $31 \%$ と有意な差がみられ，遊離空腸移植を併用した広範

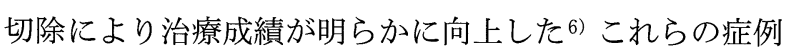
はすべて病期 III ・IV の進行癌であり，ここでいら広範切 除とは原発巣については断端におよそ $3 \mathrm{~cm}$ 以上の安全域 をつけた切除, リンパ節については両側根治的頸部郭清 に両側の傍気管・咽頭後部郭清を追加した手術である.

このように遊離空腸の利用で生存率は確かに改善した が, それでも $1 / 3$ の進行癌症例は 3 年以内に下咽頭癌で 死亡していた。 これ以上, 切除範囲を広げることは難し い. 放射線治療など手術以外の方法でさらに改善できな いかということが次の課題であった.

\section{術後放射線治療で局所制御は向上した}

広範切除術の治療成績をさらに向上させるために導入 したのが放射線の術後照射である. 当初は，空腸が放射 線に強くないことや，実際に照射後の空腸壊死例もあっ たこと6) から，50 Gy の中等度線量を両側の全頸部に照 射する方法を採用した. 大阪赤十字病院では 1994 年から 下咽頭進行癌に対して遊離空腸併用の広範切除と術後照 射 50 Gy の治療を原則的に行った. 2000 年までの治療成 績を図 3 に示す. 3 年，5 年生存率はいずれも $55 \%$ であ り, 残念ながら, 久留米大学と同程度の成績しか得られ

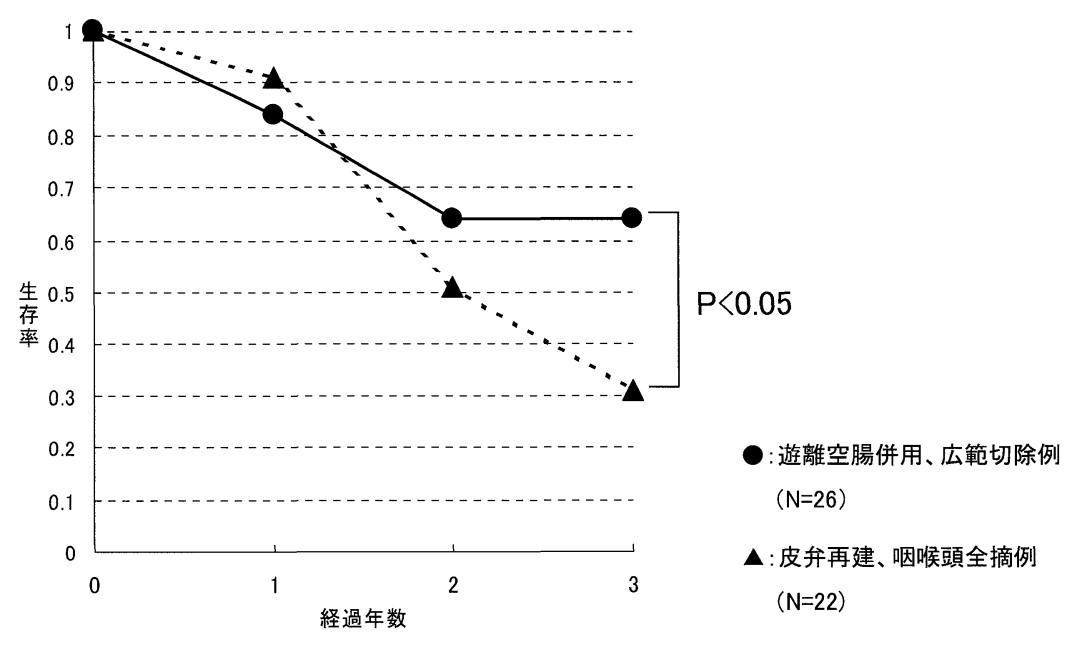

図 2 下咽頭進行癌における遊離空腸による再建群と皮弁による再建群の疾患特異的生存率 (久留米大学, 1985 ～1992) 


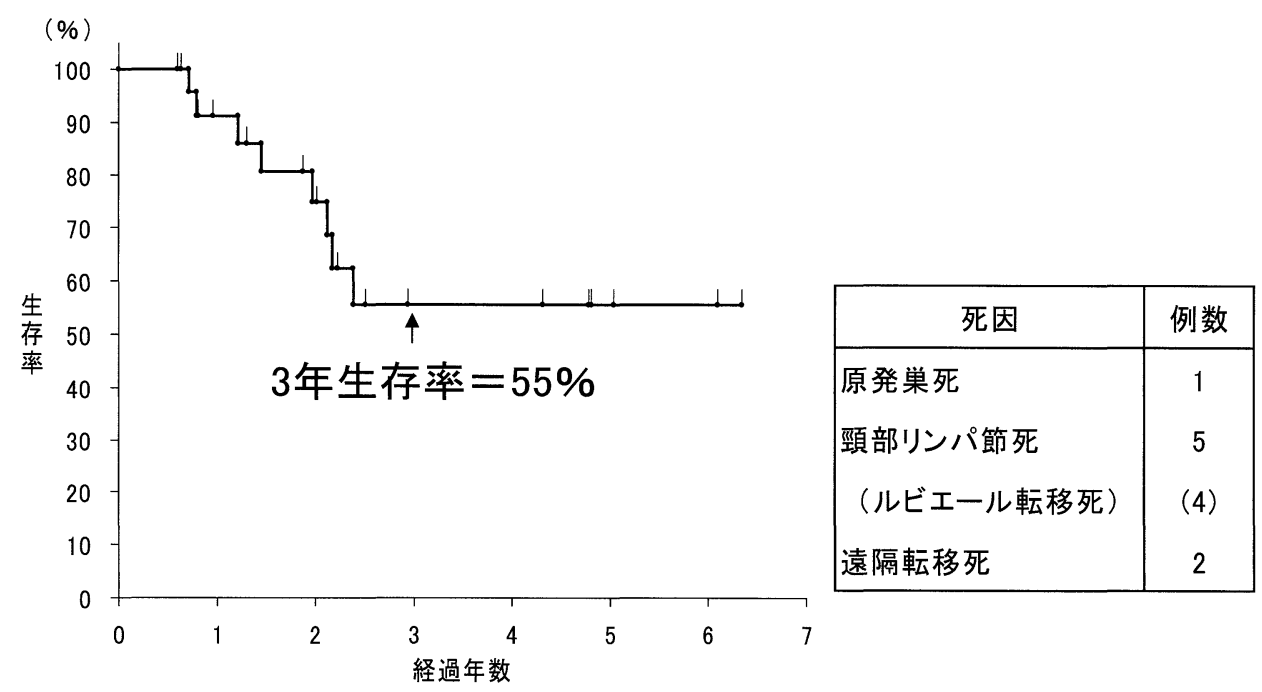

図 3 大阪赤十字病院における下咽頭進行癌の疾患特異的生存率と死因 $(\mathrm{N}=25,1994 \sim 2000$, カプランマイヤー法 $)$

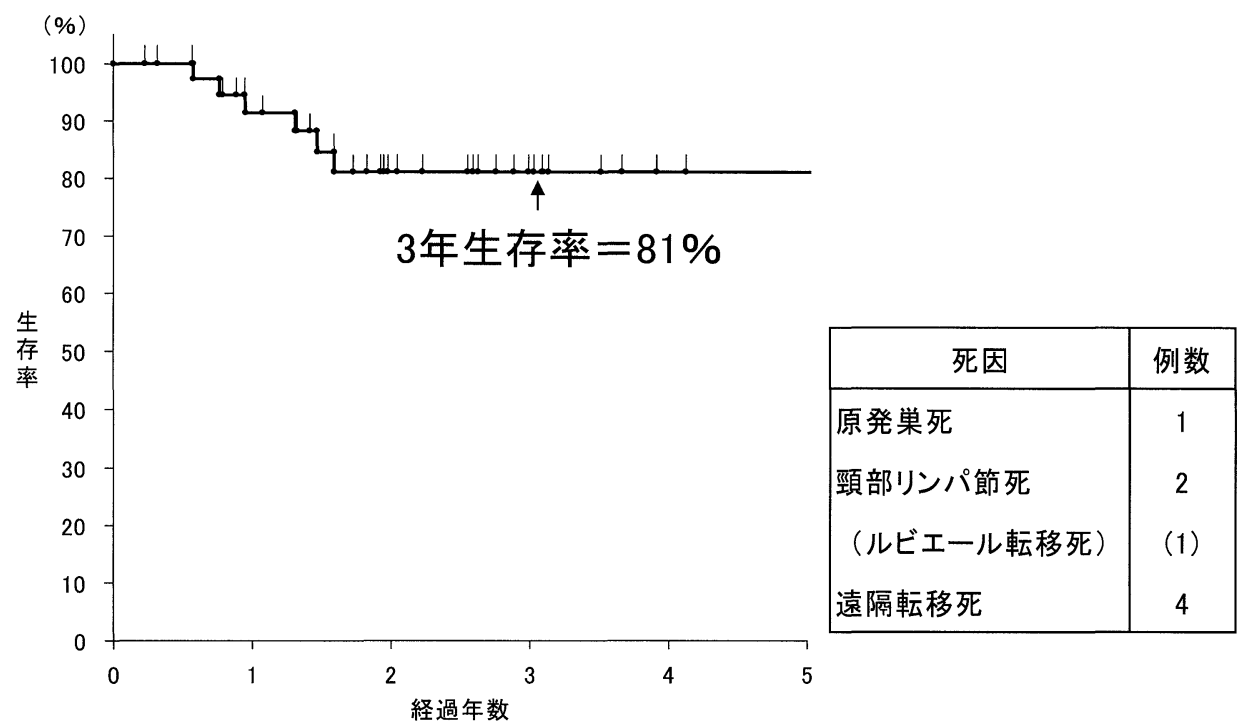

図 4 京大病院における下咽頭進行癌の疾患特異的生存率と死因 $(\mathrm{N}=39,2001 \sim 2005$ ，カプランマイヤー法）

なかった. 最も意外であったのは, 咽頭後部リンパ節 (ル ビエールリンパ節）への再発が死亡原因の半数を占めた ことであった.

従来より下咽頭癌ではルビエールリンパ節転移の制御 が難しいといわれ778), 大阪赤十字病院でも同様の結果で あった．この転移を術後の補助治療で何とか制御できな いか? 京都大学病院では, 下咽頭進行癌の術後照射につ いて放射線科と協議し, 照射前の CT シミュレーッショ
ンで両側の咽頭後部を確実に照射野に含めて両頸部に $50 \mathrm{~Gy}$ の照射を行う, 摘出標本でルビエールリンパ節に 転移があった例には転移側の咽頭後部に $10 \mathrm{~Gy}$ の追加照 射と照射中に週 1 回シスプラチン $50 \mathrm{mg} / \mathrm{body}$ の抗癌剂治 療を行ら, 3 個以上のリンパ節転移例や切除の安全域が 不足した例にも同様の追加照射と抗癌剂治療を行う, と いう方針を決め, 2000 年 6 月から施行した. 2005 年 5 月 までの治療成績を図 4 に示す。観察期間は十分とはいえ 
ないが，疾患特異的 3 年生存率は $81 \%$ と満足すべき成績 が得られている.ルビエールリンパ節への再発死は, 大 阪赤十字病院では 25 例中 4 例 $(16 \%)$ あったものが, 京 都大学病院では 39 例中 1 例 $(2.6 \%)$ に激減した。遊離 空腸を併用した広範切除に適切な放射線治療や抗癌剂治 療を追加することで下咽頭進行癌の局所制御はかなりの 例で可能であることを示したものである.

\section{早期癌の多くで機能が温存できた}

病期 I ・ II の下咽頭早期癌は進行癌に比べると, 当然, 予後は良好である。したがって, 進行癌ほどの広範切除 は必要ないし, 音声も含めた喉頭機能の温存もある程度 は可能である，それでは，どのような治療を早期癌に行 うべきであろらか? 京都大学病院では 2000 年から, 治癒 と機能温存を目的として, 放射線治療をたは機能保存手 術のどちらかを可能な限り行ってきた. 2005 年までの早 期癌 14 例の成績を表 2 に示す.これも観察期間は十分で はないが，下咽頭癌再発はなく疾患特異的 3 年生存率は $100 \%$, 機能温存率は $79 \%$ とかなり良好な成績が得られ ている．ただし，われわれの行ってきた放射線治療は下 咽頭に $70 \mathrm{~Gy}$ の分割高線量, 両頸部に $50 \mathrm{~Gy}$ を照射する 方法であり，喉頭保存手術でも患側の根治的頸部郭清は 必ず行った。喉頭早期癌に比べるとかなり濃厚な治療を 行ったことになる. 下咽頭早期癌では, 局所制御がやや 困難であること考慮して治療すれば，放射線治療でも喉 頭保存手術でも十分な成績が期待できると思われた.

ぞの施設でもこのように放射線治療は有効なのか? 筆 者は久留米大学病院, 大阪赤十字病院, 京都大学病院之 3 つの施設で癌患者の治療に携わってきたが, 放射線治 療の効果は施設間で明らかに異なることを実感してい る.したがって，放射線治療が必ずしも効果的とはいえ ない施設では，レーザーによる減量術9) や抗癌剂治療 ${ }^{10}$ を補助的に併用することは大いに意味のあることと考え

表 2 京大病院における下咽頭早期癌の治療法と成績 (2000 2005)

\begin{tabular}{ccccc}
\hline \hline 治療法 & 例数 & $\begin{array}{c}\text { 経過月数 } \\
(\text { (平均) }\end{array}$ & $\begin{array}{c}\text { 再発 } \\
\text { 例数 }\end{array}$ & $\begin{array}{c}\text { 他病 } \\
\text { 死数 }\end{array}$ \\
\hline 放射線治療 & 8 & $5 \sim 64(27)$ & 0 & 2 \\
喉頭保存手術 & 3 & $10 \sim 18(15)$ & 0 & 1 \\
咽喉頭全摘 & 3 & $23 \sim 43(33)$ & 0 & 0 \\
\hline 計 & 14 & $5 \sim 64(26)$ & 0 & 3
\end{tabular}

られる。

\section{喉頭保存手術も進歩した}

耳鼻咽喉科は外科の一分野として発展してきた。 その 自覚を強くもつものにとって, 下咽頭癌の喉頭保存手術 は最も魅力的な手術の一つである. 現状では, 残念なが ら, 治療の主体は, 機能保存に有利な放射線治療と根治 性に優れた広範切除であり, 喉頭保存手術は脇役である. 喉頭保存手術はこのまま歴史に埋もれてしまうのか? 氻 つて, 喉頭保存手術は根治性や術後の苝下障害など多く の問題を抱え, 大胸筋皮弁で再建した喉頭保存手術 ${ }^{11)}$ は誤嚥に苦労した思い出ばかりが残っている。しかしな がら, 再建技術と手術医療の進歩で喉頭保存手術も確実 に進歩している，たとえば，遊離空腸や遊離前腕皮弁の 利用により, 広い下咽頭腔が再建され ${ }^{12213)}$, 声門上部の 欠損もらまく被覆される ${ }^{14)}$. 舌骨と胸骨舌骨筋を用いた 有茎筋骨弁で声門上部欠損が確実に再建できる ${ }^{15116)}$. こ のような工夫で術後の誤嚥は明らかに少なくなってい る. また, 術中に断端組織の迅速病理検查を頻用するこ とで安全域の狭さをカバーでき, 根治性の問題もなくな るかもしれない17)。喉頭保存手術はその方法も技術もさ らに進歩する余地があり, 将来的には, 放射線治療や広 範切除に並ぶ下咽頭癌の一治療法になる可能性がある.

\section{まだまだ多くの課題が残っている}

下咽頭癌の遠隔転移は治療が難しく，うまく制御でき た例を筆者はまだ経験していない，選択的動注化学療法 と放射線照射を組み合わせた治療では局所制御が向上し たが遠隔転移が倍増したと報告されている18)が，広範切 除と術後照射を組み合わせたこれまでの治療では遠隔転 移が増大寸る傾向はない，治療法と遠隔転移発生率の関 係や遠隔転移自体の制御治療は今後の大きな課題であ る.

下咽頭癌は食道癌や口腔癌など他癌と重複することが 多い，こ机は，かつては，予後不良因子の一つであった が，いまは必ずしもそうではない，たとえば，下咽頭癌 ではルーティンに全身の癌に対する検査を行うことで他 の早期癌が見つかる. 逆に, 他癌の咽喉頭を含めた全身 検査で制御可能な下咽頭早期癌が発見できれば治癒率の 向上につながる. 実際に, 最近の京都大学病院における 下咽頭・食道重複癌例の 3 年生存率は $62 \%$ と比較的良好 な成績が得られている ${ }^{19)}$. 他癌のルーティン検查の一つ 
に咽喉頭の検查をうまく組み入れることで治療成績の改 善を目指すべきであろう。

その他, 下咽頭癌の治療には多くの課題が残っている. 機能温存に関しては，術後の運動障害と頸部郭清法の関 係，喉頭保存手術の適応範囲，選択的動注化学療法と放 射線照射を組み合わせた治療の検証などがある，放射線 治療では喉頭浮腫などの遅延性の合併症が最も大きな問 題である，遊離空腸による再建例の代用音声も解決す心゙ き課題である。

下咽頭癌治療の展望は，これらの課題がうまく解決で きるか否かによって大きく異なる，癌治療に携わる臨床 医としては，謙虚に患者の声を聞くとともに，より良い 治療を行おらというモチベーションを保ち続けることが 最も大切であると考える.

\section{参考文献}

1）田中信三，平野 実，松岡秀隆，他：下咽頭癌の治療，20 年間 173 例の検討。日気食会報 $43: 88 \sim 95 ， 1992$ 。

2) 田中信三, 平野 実, 松岡秀隆, 他：遊離空腸による下咽 頭・頸部食道の再建. 日耳鼻 $94 ： 192 \sim 197,1991$.

3) Coleman JJ, Searles JM, Hester TR, et al. : Ten year experience with the free jejunal autograft. Am J Surg 154:394 398, 1987.

4）井上要二郎, 藤田博正, 田井良明, 他：遊離空腸移植を用 いた下咽頭頸部食道再建後の嚥下障害について. 形成外科 $32: 1037 \sim 1042$, 1989.

5）田中信三：下咽頭梨状陷凹癌. JOHNS 20:1375～1377, 2004.

6）田中信三，松岡秀隆，平野 実：下咽頭進行癌に対する広 範囲切除・郭清，空腸による再建術の治療成績. 日気食会 報 $45 ： 227 \sim 233 ， 1994$ 。

7）竹生田勝次，西嶌 渡，寺田寿美子：下咽頭癌 埼玉県立 がんセンターでの治療経験. 耳喉頭頸 67:605〜 609, 1995.

8）岡本美孝，松崎全成，更級則夫：下咽頭扁平上皮癌 stage III - IV 期症例の予後因子についての検討. 耳鼻臨床 補 94 ：
$184 \sim 190,1997$.

9）森一功，千々和圭一，梅野博仁，他：下咽頭 $\mathrm{T} 1, \mathrm{~T} 2$ 癌 に対する喉頭保存治療. 日耳鼻 $103: 977 \sim 985,2000$.

10）倉富勇一郎，門田英輝，富田恵理，他：FAR 療法による喉 頭癌および下咽頭癌の喉頭保存. 耳鼻と臨 46 : S57 S62, 2000.

11) Hirano M, Kurita S, Yoshida T, et al. : Partial laryngopharyngectomy for piriform sinus carcinoma. Technique and preliminary results. Auris Nasus Larynx $15: 129 \sim 136,1988$.

12）田中信三, 平野 実, 井上要二郎, 他 : 遊離前腕皮弁によ る下咽頭癌の喉頭保存手術例. 日気食会報 $44: 231 \sim 234$, 1993.

13）田中信三，田辺正博，與那嶺裕，他：下咽頭癌の喉頭保存 手術例，下咽頭全周切除後の遊離空腸による再建術. 日気 食会報 $50 ： 569 \sim 573 ， 1999$.

14）海老原敏, 波利井清紀, 林 隆一, 他：下咽頭部分切除と 誤曣防止. JOHNS $15 ： 1227 \sim 1229,1999$.

15）田中信三, 平塚康之, 安里 亮, 他：下咽頭部分切除に抒 ける声門上部の硬的再建術. 日気食会報 $53: 275 \sim 279$, 2002.

16）田中信三，安里 亮，玉木久信，他：咽喉頭部分切除にお ける声門上部再建術。頭頸部癌 $30 ： 558 \sim 562,2004$.

17）田中信三：下咽頭がんに対する拡大手術と縮小手術，咽喉 頭部分切除術. 頭頸部外科 2006，印刷中.

18） Robbins KT, Kumar P, Harris J, et al. : Supradose intra-arterial cisplatin and concurrent radiation therapy for the treatment of stage IV head and neck squamous cell carcinoma is feasible and efficacious in a multi-institutional setting: results of Radiation Therapy Oncology Group Trial 9615. J Clin Oncology 23 : $1447 \sim 1454,2005$

19）田中信三, 安里 亮, 岸本正直, 他：下咽頭癌の食道癌重 複例について。頭頸部癌 $31: 543 \sim 552,2005$.

別刷請求先：田中信三

空606-8507 京都市左京区聖護院川原町54 京都大学大学院医学研究科耳鼻咽喉科・頭頸部外科感 覚運動系外科外科学講座 